\title{
Mode resolved density of atmospheric aerosol particles
}

\author{
J. Kannosto ${ }^{1}$, A. Virtanen ${ }^{1}$, M. Lemmetty ${ }^{1}$, J. M. Mäkelä ${ }^{1}$, J. Keskinen ${ }^{1}$, H. Junninen ${ }^{2}$, T. Hussein ${ }^{2}$, P. Aalto ${ }^{2}$, and \\ M. Kulmala ${ }^{2}$ \\ ${ }^{1}$ Aerosol Physics Laboratory, Department of Physics, Tampere University of Technology, P.O. Box 692, \\ 33101 Tampere, Finland \\ ${ }^{2}$ Department of Physics, University of Helsinki, P.O. Box 64, 00014 Uhel, Finland
}

Received: 22 February 2008 - Published in Atmos. Chem. Phys. Discuss.: 15 April 2008

Revised: 6 August 2008 - Accepted: 6 August 2008 - Published: 8 September 2008

\begin{abstract}
In this study, we investigate the mode resolved density of ultrafine atmospheric particles measured in boreal forest environment. The method used here enables us to find the distinct density information for each mode in atmospheric fine particle population: the density values for nucleation, Aitken, and accumulation mode particles are presented. The experimental data was gained during 2 May 2005-19 May 2005 at the boreal forest measurement station "SMEAR II" in Hyytiälä, Southern Finland. The density values for accumulation mode varied from 1.1 to $2 \mathrm{~g} / \mathrm{cm}^{3}$ (average $1.5 \mathrm{~g} / \mathrm{cm}^{3}$ ) and for Aitken mode from 0.4 to $2 \mathrm{~g} / \mathrm{cm}^{3}$ (average $0.97 \mathrm{~g} / \mathrm{cm}^{3}$ ). As an overall trend during the two weeks campaign, the density value of Aitken mode was seen to gradually increase. With the present method, the time dependent behaviour of the particle density can be investigated in the time scale of $10 \mathrm{~min}$. This allows us to follow the density evolution of the nucleation mode particles during the particle growth process following the nucleation burst. The density of nucleation mode particles decreased during the growth process. The density values for $15 \mathrm{~nm}$ particles were $1.2-1.5 \mathrm{~g} / \mathrm{cm}^{3}$ and for grown $30 \mathrm{~nm}$ particles $0.5-1 \mathrm{~g} / \mathrm{cm}^{3}$. These values are consistent with the present knowledge that the condensing species are semi-volatile organics, emitted from the boreal forest.
\end{abstract}

\section{Introduction}

Atmospheric aerosol contains a complex mixture of particles of the natural and the anthropogenic origin, consisting of both primary and secondary particles from a variety of sources (e.g. Seinfeld and Pandis, 1998). Its chemical and elemental composition, optical, hygroscopic and other phys-

Correspondence to: A. Virtanen

(annele.virtanen@tut.fi) ical and chemical properties vary both spatially and temporally. Additionally, there is variation of all these quantities over particle size. The assessment of the climatic and the adverse health effects of atmospheric aerosol particles requires detailed information on particle properties (Yu et al., 2006; Lohmann and Feichter, 2005; Pope and Dockery, 2006). For example, the particle size and chemical composition affect the particle residence time in the atmosphere, its optical properties and its potential to act as a cloud condensation nuclei as well as its behaviour in human lungs. In addition, the chemical composition and other chemical and physical properties of the particles carry information concerning sources and the formation mechanisms of particles.

Atmospheric fine particles can be classified to ultrafine $\left(d_{b}<100 \mathrm{~nm}\right)$ and accumulation mode $\left(100 \mathrm{~nm}<d_{b}<1 \mu \mathrm{m}\right)$ particles. The ultrafine particles can be further divided into nucleation $(<30 \mathrm{~nm})$ and Aitken mode particles $\left(30 \mathrm{~nm}<d_{b}<100 \mathrm{~nm}\right)$. The ultrafine size range dominates the particle number concentration, and in urban areas usually contributes to more than $90 \%$ of particle total number. Generally, after their formation, the fresh aerosol particles in the atmosphere appear in this size range. In addition, being also in the critical size range for acting as cloud condensation nuclei, the ultrafine size range affects the number concentration of cloud droplets in remote and moderately polluted environments.

The composition and properties of accumulation mode particles are fairly well known because proper measurement and analytical methods have been available for this size range and mass concentration level (e.g. Wall et al., 1988; Maenhaut et al., 1999; Putaud et al., 2004). A few studies in distinct locations have provided also information on the composition of the ultrafine size mode, such as the existence of polycyclic aromatics in urban aerosol (Allen et al., 1998); overall urban aerosol at around $100 \mathrm{~nm}$ (Cass et al., 2000); the elemental composition of chlorine in sub $10 \mathrm{~nm}$ coastal aerosol (Mäkelä et al., 2002); distinct chemical components,

Published by Copernicus Publications on behalf of the European Geosciences Union. 


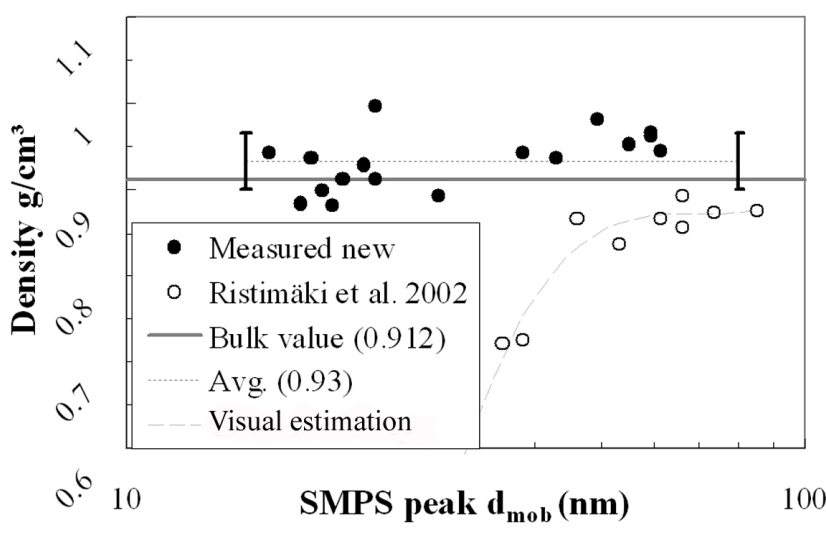

Fig. 1. Laboratory tests of the method using DOS particles. The results gained by carefully calibrated impactor kernels (black dots) are compared to inaccurate kernels (open circles). Average density value of black dots is 0.93 . The gray dashed line is result of visual estimation. Figure adapted from Ristimäki (2006).

such as amines, in boreal forest (Mäkelä et al., 2001a), organics vs. in-organics in boreal forest (O'Dowd et al., 2002) and organics in coastal aerosol (Vaattovaara et al., 2006). Recent results obtained using mass spectrometers give first insights to the full chemical composition of ultrafine particles (Zhang et al., 2005; Smith et al., 2005; Allan et al., 2006). However, there are still clear gaps in the overall knowledge about the ultrafine size range particles.

Nucleation bursts observed in different environments produce nucleation mode particles in the atmosphere (Kulmala et al., 2004a). There have been intensive and successful efforts to identify different nucleation mechanisms (e.g. Kulmala et al., 2006). Regardless of the progress, there are still gaps in the general understanding of the new particle formation and between the experimental data and the models. In the experimental data, there are for example long time series available showing particle size evolutions after nucleation events (e.g. Dal Maso et al., 2005) but the observations of composition and properties of the particles are mostly lacking. It is not clear which compounds are responsible for condensational growth process of nucleation mode particles (e.g. Zhang e t al., 2004a; Kulmala et al., 2004b). Since these events of new particle formation are observed to take place practically everywhere in the boundary layer, even in the polluted areas (e.g. Harrison et al., 2000; Wehner and Wiedensohler, 2003; Wehner et al., 2005; Alam et al., 2003; Charron et al., 2007), it is probable that several compounds can be potentially participating in the growth, resulting in a variety of aerosol particle compositions. A number of different organic species have been linked with the particle growth process in the natural forest environment (e.g. O'Dowd, 2002; Zhang et al., 2004b; Tarvainen et al., 2005; Laaksonen et al., 2008).

As a property complementary to particle composition, the density of the particles is of great interest. Accumulation and coarse mode particle density has been studied e.g. by Mc-
Murry et al. (2002) and Saarikoski et al. (2005). In this study, we investigate the mode resolved density of atmospheric ultrafine particles in boreal forest environment, using a density fitting method (e.g. Virtanen et al., 2006). Preliminary, time averaged density values have been discussed by Kannosto et al. (2006). Here we present the analysis of the full data set, reporting values for nucleation, Aitken, and accumulation modes and, as a new aspect, we study the time dependent behaviour of the particle density. This allows us to follow the density change of the particles during the particle growth process following a nucleation burst.

\section{Method description}

Particle density was estimated using the parallel measurement method developed at Tampere University of Technology, first described by Ristimäki et al. (2002). The method is based on a simultaneous ("parallel") distribution measurement with an electrical low pressure impactor (ELPI) and a scanning mobility particle sizer (SMPS) or a differential mobility particle sizer (DMPS) and, further, on the relationship between particle aerodynamic size, mobility size and effective density. First applied to laboratory aerosols and diesel exhaust particles, the method has been developed further to be suitable for an atmospheric aerosol (Virtanen et al., 2006; Kannosto et al., 2006). We have now modified the data treatment method to be suitable for large data series and multimodal distributions, which are typical for boreal forest environment.

As the shape of the aerosol distributions is commonly relatively close to lognormal distributions, the measured number distribution on mobility axis is divided into lognormal subdistributions (modes). The automatic algorithm described by Hussein et al. (2005) is used in fitting the lognormal distributions to measured DMPS or SMPS data. In order to find the correct density for each mode the ELPI response to the multi-modal distribution is simulated. In the calculation of the simulated ELPI currents, a mathematical model of ELPI is used. The complete set of information, required to construct the mathematical model of ELPI, can be found in Marjamäki et al. (2005).

In the calculation of the simulated currents, the effective density of the particles is needed. By changing the effective densities of modes the simulated ELPI currents are changed. The simulated ELPI currents are obtained by summing the currents produced by each sub-distribution. The main difference to the single mode case (Ristimäki et al., 2002) is that instead of one effective density, effective density for each mode is searched. This means that the search algorithm has to operate in multi-dimensional space and the result may be more sensitive to the starting point than with the single mode case. Several methods can be used to define the starting point for the search algorithm. We have initialized the effective densities with an ad hoc method where the initial effective 
densities are suggested in a sequence starting from the distribution which contributes most to the ELPI current and ending with the one which contributes least. These contributions can be easily calculated as the total current produced by the distribution does not depend on the effective density. The actual initialisation of each mode is performed by utilizing a set of pre-selected densities ranging from 0.1 to $10 \mathrm{~g} / \mathrm{cm}^{3}$, and defining the density which gives the smallest difference between measured and simulated currents. After the initialisation, the search algorithm (the "fminsearch" function of Matlab( $\left.{ }^{\circledR}\right)$ minimises the difference between the measured and simulated ELPI currents by changing the effective densities of each mode.

\subsection{Method evaluation}

The method used in this article has been previously evaluated in a laboratory setting by Virtanen et al. (2006). They used laboratory aerosols with bimodal size distributions. The particles consisted of Fomblin (perfluorinated polyether inert fluid, Ausimont Ltd, $\rho=1.9 \mathrm{~g} / \mathrm{cm}^{3}$ ) and di-octyl sebacate (DOS, $\rho=0.91 \mathrm{~g} / \mathrm{cm}^{3}$ ) and the geometric mean diameters of the two modes were varied between $40-150 \mathrm{~nm}$. The method produced density estimates of $(0.8 \pm 0.08) \mathrm{g} / \mathrm{cm}^{3}$ and $(1.8 \pm 0.26) \mathrm{g} / \mathrm{cm}^{3}$ for DOS and Fomblin, respectively. Some additional laboratory tests with DOS and smaller particle sizes were performed by Ristimäki (2006). Ristimäki calibrated the impactor using DOS particles monodispersed by differential mobility analyzer (DMA). In calibration, both the impactor cut-off curves and the charger efficiency were determined. The ELPI impactor cut-off curves were determined by the method described by Keskinen et al. (1999) and the charge efficiency was calibrated following the method described by Marjamäki et al. (2000). In addition, the DMPS used in this study was calibrated and the calibration is described by Aalto et al. (2001). In Fig. 1, the results measured with a carefully calibrated impactor are shown (black dots in Fig. 1). The lowest mode size measured was $13 \mathrm{~nm}$. The agreement with the bulk value of DOS (gray line in Fig. 1) and the measurement results is good. In Fig. 1, also the earlier laboratory test results reported by Ristimäki et al. (2002) are shown (open circles). The points in the figure are calculated using the older impactor kernel functions, which had some inaccuracy in the cut-off curve of the first impactor stage. The inaccuracy was revealed when the impactor was re-calibrated. The figure shows that a careful calibration of the impactor is essential: the method fails in particle sizes smaller than $30 \mathrm{~nm}$, when the inaccurate cut-off curve of the first stage was used.

Because of the number of variables affecting the performance of the method, laboratory tests are not an efficient way to determine the restrictions of the density fitting method. Thus, a large number of simulations were made to determine the "detection limit" of the method. In the simulations, the "input" DMPS distributions were first generated based on the measured Hyytiälä data: the distributions consisted of three lognormal modes in the size range of nucleation, Aitken and accumulation modes. After that, the density values ranging from 0.5 to $2 \mathrm{~g} / \mathrm{cm}^{3}$ were given to each mode. The corresponding ELPI currents were then simulated by means of size distributions, given densities and ELPI instrument functions (i.e. impactor kernels and charger efficiency). The simulations were created by adding 5\% noise to ELPI currents and DMPS distributions. After that the density of each mode was found using the simulated currents and the DMPS size distribution data. The simulations show that the detection limit depends mainly on the GMD of the modes and the relative concentration of the modes. According to the simulation runs, the density analyzing method is capable to evaluate the density of the nucleation mode particles in multimodal distribution, even when the smallest mode GMD is around $15 \mathrm{~nm}$. The density results of the nucleation mode particles in multimodal distributions can be found if circumstances are favourable. First of all, this requires sufficiently high concentrations to obtain a good mode fitting result from the SMPS/DMPS measurement. In addition, the nucleation mode must generate enough current in the ELPI in order arrive at a reliable density estimate with out method. If approximately $20 \%$ of the measured current is produced by the mode, the density value can be found. These restrictions are valid for all modes regarding to their peak size. In Table 1 we have presented the minimum ELPI total current values that can be analyzed reliably and the current which one mode has to produce (i.e. $20 \%$ of the total current). We have also calculated the mode concentrations which produce the required current. The calculations have been computed for two cases: for nucleation mode (peak size $20 \mathrm{~nm}$ ) and for accumulation mode (peak size $200 \mathrm{~nm}$ ).

According to method runs made with simulated data, there is a situation when the method has an increased possibility to yield incorrect density results even if the above current criterion was fulfilled. The situation is encountered in the case where two modes both generate approximately the same amount of ELPI current. In this case, when generating the ELPI response, the two modes may swap places on the aerodynamic axis ("mode swapping"). This can be recognized as one mode receives an improbably high density value $\left(d_{p}>7 \mathrm{~g} / \mathrm{cm}^{3}\right)$, while the other one receives an improbably low one $\left(d_{p}>0.2 \mathrm{~g} / \mathrm{cm}^{3}\right)$. The mode swapping cases were sorted from the resulted density values. After that each case was checked separately by calculating the resulted aerodynamic mode sizes. Both types of error can be recognized and the erroneous density values can be removed during the data analysis. Overall, the restrictions that should be taken into account in data analysis are "mode swapping" and current limitations (mode must produce $>20 \%$ of the total current). When all the restrictions were taken into account $42 \%$ of analyzed size distributions resulted unreliable density value and the results were rejected and $58 \%$ were taken to the further result analyse. 
Table 1. Minimum current and concentration requirement.

\begin{tabular}{llll}
\hline Minimum total current & $\begin{array}{l}\text { Current produced by one } \\
\text { mode }(20 \%)\end{array}$ & $\begin{array}{l}\text { Corresponding } \\
\text { concentration, } \\
\text { nucleation mode GMD } \\
20 \mathrm{~nm}\end{array}$ & $\begin{array}{l}\text { Corresponding } \\
\text { concentration, } \\
\text { accumulation mode } \\
\text { GMD 200 nm }\end{array}$ \\
\hline $50 \mathrm{fA}$ & $10 \mathrm{fA}$ & $10400 \# / \mathrm{cm}^{3}$ & $240 \mathrm{\#} / \mathrm{cm}^{3}$ \\
\hline
\end{tabular}
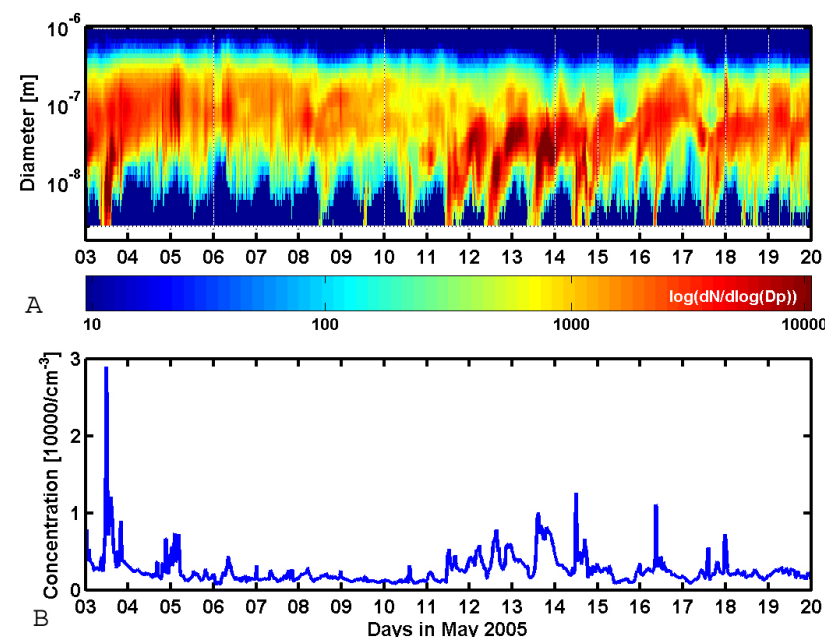

Fig. 2. The number size distributions and total number concentrations measured during the campaign. The concentrations are presented as a contour plot (Fig. 2a) and as a time series (Fig. 2b).

The sensitivity of the particle density calculation to measurement errors was investigated using the method first employed by Virtanen et al. (2004). In order to see how easily the particle density results are affected by the measurement error, we took the existing measurement data and added random, normally distributed $5 \%$ noise component to each of the measured ELPI current channel. For each measurement point, the density analysis was then run with 100 noisy samples. In most cases, the standard deviation of the density result was less than $10 \%$. We used high standard deviation values to remove the less reliable data points from further analysis. The measurement points where the added noise caused mode swapping received high standard deviation and the points were removed. The data points with one dominant mode tended to receive high standard deviation values for the less dominant mode density. The density data for the less dominant mode was removed from the analysis. As the more dominant mode density values did not receive high standard deviation, they were not removed.

\section{Description of measurement campaign}

The experimental data was gained during 2 May 2005-19 May 2005 at the boreal forest measurement station "SMEAR II” in Hyytiälä $\left(61^{\circ} 51^{\prime} \mathrm{N}, 24^{\circ} 17^{\prime} \mathrm{E}, 181 \mathrm{~m}\right.$ a.s.l.), Southern Finland. Hyytiälä is a background measurement station at Southern Finland and around the SMEAR there are extended areas of Scots Pine (Pinus sylvestris). Number concentrations are of the typical background level except when the wind blows between the directions $215^{\circ}-265^{\circ}$ where the city of Tampere and the station "SMEAR II" buildings are located. During the 16th (from noon) and 18th (until the morning) May the instruments were not in use. The measurement site has been presented in more detail by Kulmala et al. (2001) and by Hari and Kulmala, 2005).

The particle size distributions were measured with four separate instruments: ELPI (Dekati Ltd),the outdoor ELPI (Dekati Ltd), SMPS (CPC 3025, DMA 3071, TSI), and DMPS (two Vienna type DMAs, with $11 \mathrm{~cm}$ and $28 \mathrm{~cm}$ tube lengths, CPC 3025, CPC 3010 (Mäkelä et al., 1997). The measurement range of ELPI (with $10 \mathrm{lpm}$ flow) and the outdoor ELPI (with $30 \mathrm{lpm}$ flow) was $7 \mathrm{~nm}-6 \mu \mathrm{m}$ and the measurement time resolution was one minute. The SMPS size range was about $10 \mathrm{~nm}-400 \mathrm{~nm}$ and the time resolution ten minutes. The DMPS data was a combination of two parallel DMPS data and the overall measurement size range was range approximately $3 \mathrm{~nm}-500 \mathrm{~nm}$. All the size ranges were given as particle diameters. The measurement instruments were located in two different cottages (ELPI and SMPS in one and the outdoor ELPI and DMPS in another) and the distance between the two cottages was approximately $70 \mathrm{~m}$. The residence time in the sampling lines of ELPI $(10 \mathrm{lpm})$ was five seconds and the calculated diffusion losses in the sampling lines for $15 \mathrm{~nm}$ particles were approximately one percent. These losses were not corrected in the ELPI data. In the DMPS data, the losses were corrected according to the "standard" data processing of the SMEAR station (see Aalto et al., 2001). The results that are shown in this paper were measured using DMPS and ELPI (10lpm) unless otherwise noted.

The weather during the measurements was typical for the Finnish spring. Temperature varied between 1 and $22^{\circ} \mathrm{C}$ and the average temperature during daytime and night-time was $10^{\circ} \mathrm{C}$ and $5^{\circ} \mathrm{C}$, respectively. The wind direction during 
the first days (2-8 May 2005) was between South-West and South-East $\left(100^{\circ}-217^{\circ}\right)$ and during $8-14$ May 2005 the wind direction turned towards north $\left(300^{\circ}-50^{\circ}\right.$ most of the time) and during the last days (15-19 May 2005), the wind direction was mainly $150^{\circ}-260^{\circ}$. There was some rain on 3 May 2005 and on 5 May 2005 evening and night, on 15 May 2005 day and night and during the night 16-17 May 2005. In Fig. 2, the particle concentrations measured during the campaign are presented as a contour plot (Fig. 2a) and as a time series (Fig. 2b). The particle formation episodes were recorded during May 3rd, 8th, 11th-15th and 17th-18th 2005.

\section{Results}

In Fig. 3, all the density values gained during the campaign are plotted as a function of mode GMD. The atmospheric particles are typically grouped into different modes according to mode GMD (Mäkelä et al., 2001b). In our data treatment, we have also grouped the results according to the mode diameter. All the GMD values presented in this paper are mobility equivalent sizes unless otherwise mentioned. As it can be seen, the density of nucleation mode particles (15-30 nm) varies between 0.5 and $1.5 \mathrm{~g} / \mathrm{cm}^{3}$. Let us next investigate the density results of the Aitken and accumulation mode particles. In Fig. 3, the density values have been grouped to nucleation, Aitken and accumulation modes according to the mode diameter. For Aitken mode particles, we have chosen the size range 30-70 $\mathrm{nm}$ instead of the often used 30-100 nm (e.g. Hussein et al., 2004; Koponen et al., 2003). The chosen size range can be justified when Fig. 3 is investigated in more detail. It shows that the particle density values are separated into two groups, depending on their mode GMD. The particles with the mobility based mode diameter smaller than $70 \mathrm{~nm}$ clearly have lower density values than the larger particles. The separation of atmospheric aerosol particles into different modes is based on the assumption that the modes have different origins (e.g. Seinfeld and Pandis, 1998). Thus it can be assumed that the modes have also different compositions and densities. The clearly distinguishable density values of the particles in the two groups shown in Fig. 3 support this assumption. According to these results, we can conclude that during our measurement campaign in Hyytiälä the justified (mobility based) size limit for Aitken and accumulation modes was around $70 \mathrm{~nm}$. It seems that the particle density measurement provides valuable information that can be used when the particles are to be separated into Aitken and accumulation modes. Such a clear difference in the density values of Aitken mode and nucleation mode particles was not detected.

The density results reported in this study were also compared to the values reported by Saarikoski et al. (2005) (Fig. 3). They studied the chemical composition of the particles collected with a low pressure impactor in Hyytiälä. The

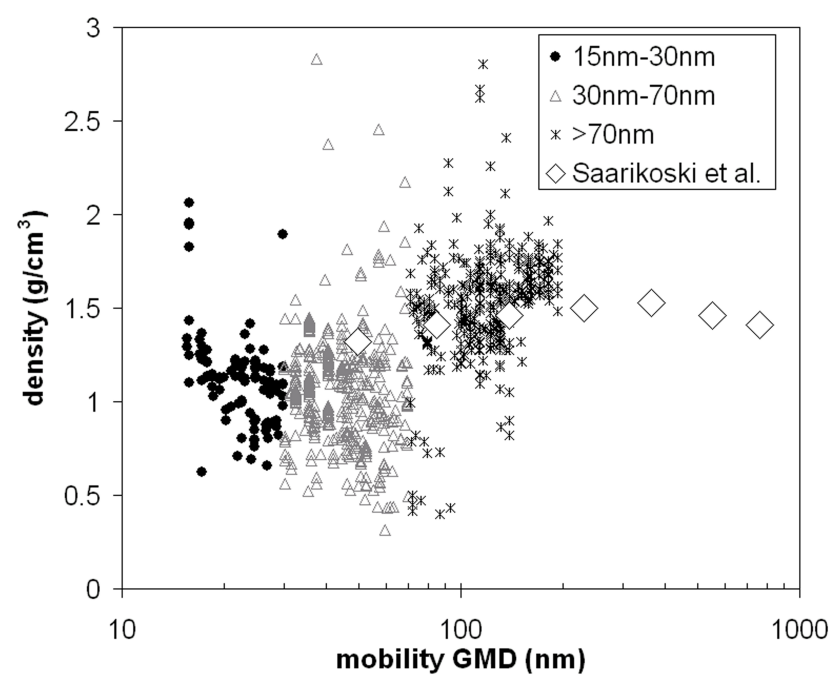

Fig. 3. Mode densities as a function of the mode GMD. The results of Saarikoski et al. (2005) are also presented (open diamonds).

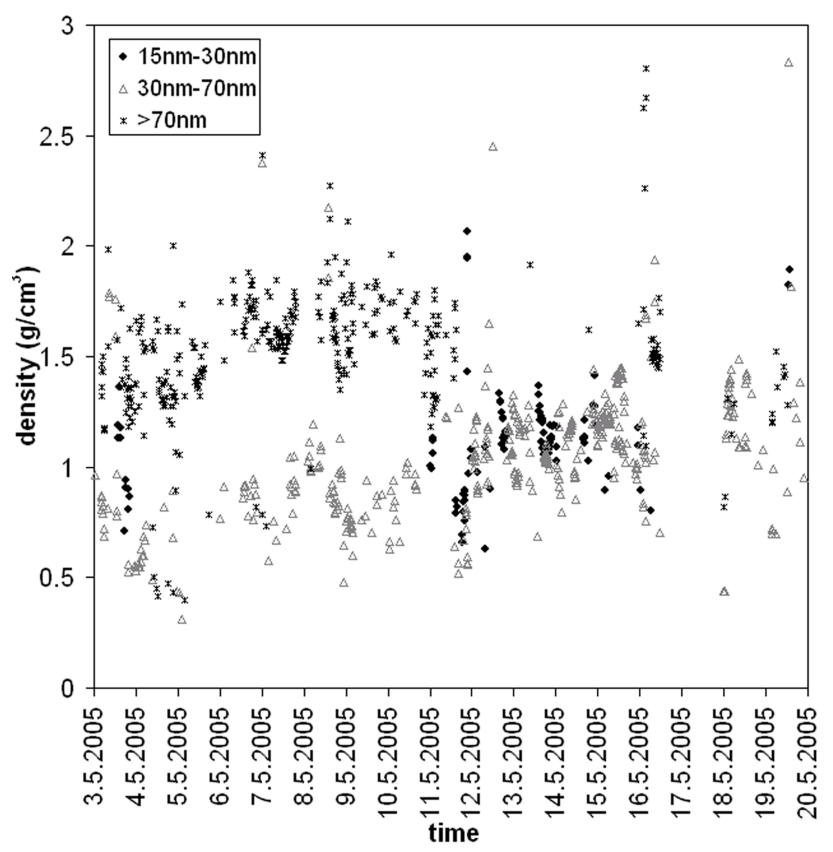

Fig. 4. Particle densities presented as a function of time.

density was derived from the mass closure analysis. The agreement of the results presented by Saarikoski et al. (2005) and the results presented in this paper is good. The comparison of the results in the size range smaller than $50 \mathrm{~nm}$ can not be done, because our results are the first ones in this size range. During the campaign the size distributions were measured with SMPS and DMPS and also with ELPI (10lpm) and the outdoor ELPI ( $30 \mathrm{lpm}$ ) as mentioned in the previous section. The densities which were gained using different instrument pairs were in good agreement: the difference was 


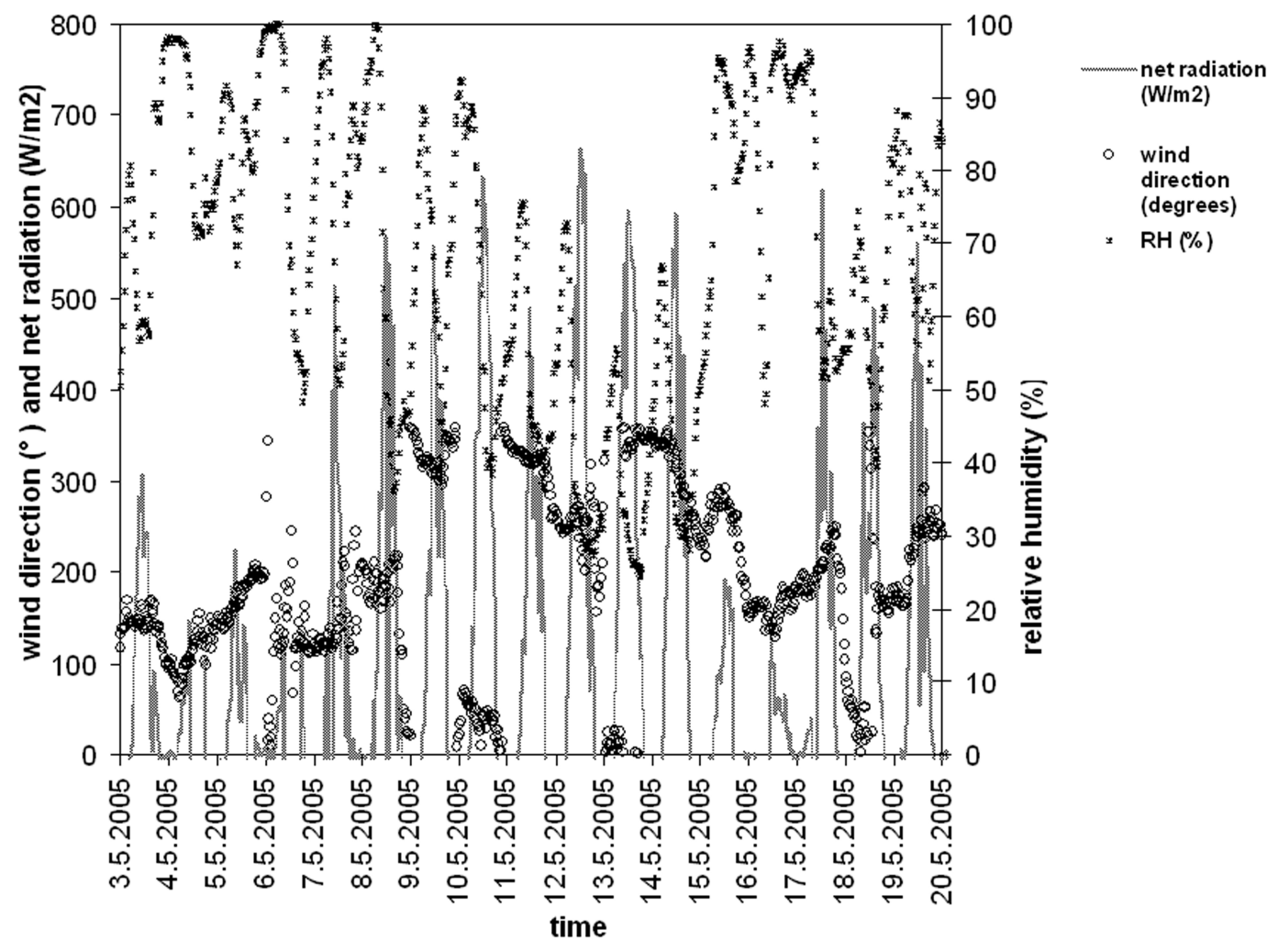

Fig. 5. Particle weather parameters during the measurement campaign. Wind direction (open circle), net radiation (solid line) and relative humidity (black star) as a function of time.

$17 \%$ at the maximum (Kannosto et al., 2006). This confirms that the density analyzing method can be applied to different instrument pairs having different characteristics if the instruments are carefully calibrated as the case was here.

The particle density results plotted at the time axis are shown in Fig. 4, where the density values of the nucleation mode particles (black dots in Fig. 4) with $15 \mathrm{~nm}<\mathrm{GMD}<30 \mathrm{~nm}$, Aitken (GMD 30-70 nm, open triangles in Fig. 4) and accumulation (GMD $>70 \mathrm{~nm}$, black stars in Fig. 4) mode particles are presented. From the evening of 16th May 2005 to the morning of 18th May 2005 the instruments were not in use. Thus, the corresponding data points are missing in Fig. 4. As shown in Fig. 4, the density values of the Aitken mode varied from 0.4 to $2 \mathrm{~g} / \mathrm{cm}^{3}$ (average $0.97 \mathrm{~g} / \mathrm{cm}^{3}$ ) and the values for the accumulation mode varied from 1.1 to $2 \mathrm{~g} / \mathrm{cm}^{3}$ (average $1.5 \mathrm{~g} / \mathrm{cm}^{3}$ ). The density values found for the accumulation mode agreed well with those reported in other studies (McMurry et al., 2002; Virtanen et al., 2006; Saarikoski et al., 2005; Cozic et al., 2008).

In Fig. 2, the particle size distribution evolution during the two week campaign is shown. In the beginning of the campaign, on 3rd May, clear particle formation occurred. Between 4th-10th May, no particle formation events were detected. After 11th May, the particle formation started again. Thus, the campaign could be divided into two periods: 4th- 10th May constituted the first period and 11th-20th May constituted the second period. The Aitken and the accumulation mode particle densities had the lowest values in the beginning of the campaign, i.e. during the first period, when no particle formation occurred. During the particle formation episodes that took place at 11th-15th May, the relative concentration of the accumulation mode particles was too low for a successful density analysis. The density values of the Aitken mode increased during the campaign and reached their maximum value at 14 th-18th of May. The highest values of the Aitken mode densities $\left(0.9-1.3 \mathrm{~g} / \mathrm{cm}^{3}\right)$ were recorded in the period during which the particle formation events occurred. This indicates that the composition of the Aitken mode particles also changes during that period. This may be a consequence of the condensation of volatile species on the particles. The increasing density of Aitken mode particles coincided with decreasing relative humidity and increasing solar radiation, accompanied with a turn in the wind direction towards north (Fig. 4 and Fig 5.). However, a larger amount of data is required before the dependence of the particle density on the different (meteorological) parameters can be properly analyzed. The density values for the nucleation mode particles were obtained only when the particle concentration was adequate and the mode diameter equal or larger than $15 \mathrm{~nm}$. According to the simulations, 

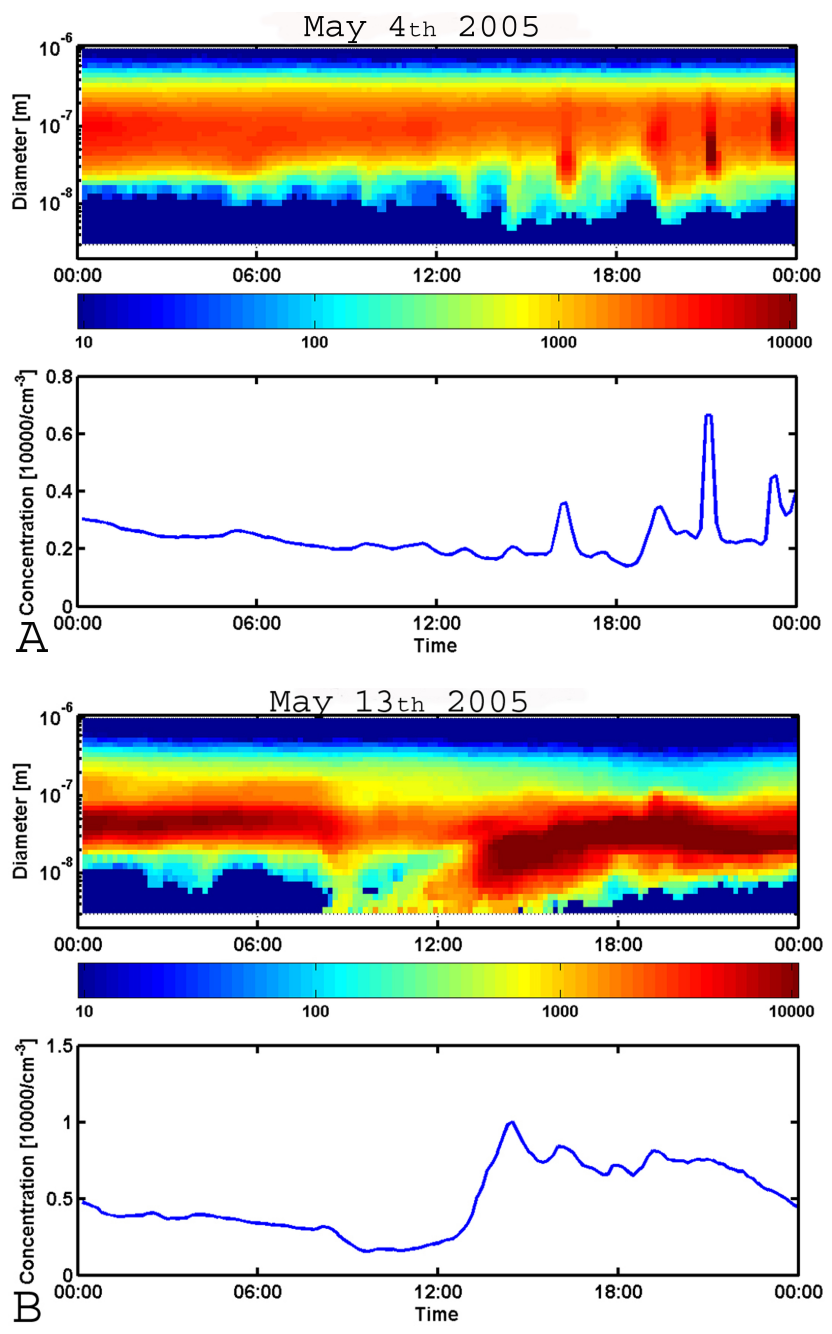

Fig. 6. Particle concentrations and size evolution on 4th May (a) and 13th May (b).

the nucleation mode particle concentration was sufficient for a density analysis if the nucleation mode particles produced $20 \%$ of the current measured with ELPI. This requirement was fulfilled during the particle formation events. The density of growing nucleation mode particles was lower during 11th May than during 12-14th May. This follows the overall density progress of the Aitken mode particles during those days. Further, this refers to the same origin of the nucleation and the Aitken mode particles. On 16th May a particle formation event occurred in the afternoon when our measurement devices were not in use.

In order to investigate the trends in particle density more thoroughly, two days, which differed in particle dynamics, were chosen. 4th May was a day with practically no nucleation mode present (Fig. 6a) whereas on 13th May there was an intense particle formation event and a high nucleation mode concentration in the afternoon (Fig. 6b). The mean values of the weather parameters and some gas component
Table 2. Weather parameters on 4th and 13th May.

\begin{tabular}{rrll}
\hline 13 May 2005 & 4 May 2005 & units & \\
\hline 10.4 & 5.9 & ${ }^{\circ} \mathrm{C}$ & Temperature \\
-0.004 & -0.006 & ${ }^{\circ} \mathrm{C}$ & $\begin{array}{l}\text { potential T } \\
\text { gradient }\end{array}$ \\
& & & $\mathrm{RH}$ \\
38.9 & 86.7 & $\%$ & $\mathrm{H}$ \\
4.6 & 7.9 & $\mathrm{ppth}$ & $\mathrm{H}_{2} 0$ \\
196.2 & 115.0 & $\circ$ & wind direction \\
14.69 & 5.1 & $\mathrm{~W} / \mathrm{m}^{2}$ & UV-A \\
28.9 & 9.9 & $\mathrm{~W} / \mathrm{m}^{2}$ & UV-A, \\
& & & during daytime \\
0.57 & 0.21 & $\mathrm{~W} / \mathrm{m}^{2}$ & UV-B \\
1.2 & 0.43 & $\mathrm{~W} / \mathrm{m}^{2}$ & UV-B \\
& & & during daytime \\
175.4 & 36.0 & $\mathrm{~W} / \mathrm{m}^{2}$ & Net Radiation \\
417.1 & 93.9 & $\mathrm{~W} / \mathrm{m}^{2}$ & Net Radiation, \\
& & & during daytime \\
49.7 & 26.7 & $\mathrm{~km}$ & Visibility \\
0.73 & 1.61 & $\mathrm{ppb}$ & NOx \\
0.0004 & 0.013 & $\mathrm{ppb}$ & NO \\
45.3 & 42.3 & $\mathrm{ppb}$ & $0_{3}$ \\
384.7 & 387.0 & $\mathrm{ppm}$ & CO 2 \\
0.08 & 0.10 & $\mathrm{ppb}$ & $\mathrm{SO}_{2}$ \\
& & &
\end{tabular}

UV-A ultraviolet radiation in wavelength range $0.32-0.40 \mu \mathrm{m}$ in units $\mathrm{W} / \mathrm{m}^{2}$

UV-B ultraviolet radiation in wavelength range $0.28-0.32 \mu \mathrm{m}$ in units $\mathrm{W} / \mathrm{m}^{2}$

Net radiation is the difference between the incoming and outgoing radiation, wavelength range is $0.30-40 \mu \mathrm{m}$ in units $\mathrm{W} / \mathrm{m}^{2}$

concentrations of the two days are presented in Table 2. In Fig. $7 \mathrm{c}-7 \mathrm{~d}$, the mode densities are plotted as functions of time. The corresponding GMD sizes are shown in Fig. 7a and $7 \mathrm{~b}$. It should be noted here that in Fig. $7 \mathrm{a}-7 \mathrm{~b}$ only the GMD values of the modes whose density analysis was successful are shown. The error bars show the standard deviation estimated using the method described in Sect. 2 of this paper.

During the 4th May (Fig. 6a), the particle population was stable and no remarkable changes in the GMDs and the concentrations of modes occurred except the two concentration spikes in the evening and the night on 4th May. The spikes were obvious local pollution episodes: $\mathrm{NO}_{\mathrm{x}}, \mathrm{CO}_{2}$ concentrations hadpeak values at the same time and $\mathrm{O}_{3}$ concentration had negative peak. On 4th May also the particle density values were stable and the density values for the Aitken mode were very low: $(0.5 \pm 0.2) \mathrm{g} / \mathrm{cm}^{3}$ (Fig. 7c). The accumulation mode densities were approximately $(1.4 \pm 0.2) \mathrm{g} / \mathrm{cm}^{3}$ during the whole day (Fig. 7c). 4th May represents the first days of the campaign during which the particle density was low and no particle formation events were recorded.

On 13th May (Fig. 7b) a particle formation event took place at 12:00 noon. During the particle formation event and the growth process, the nucleation mode concentration was 

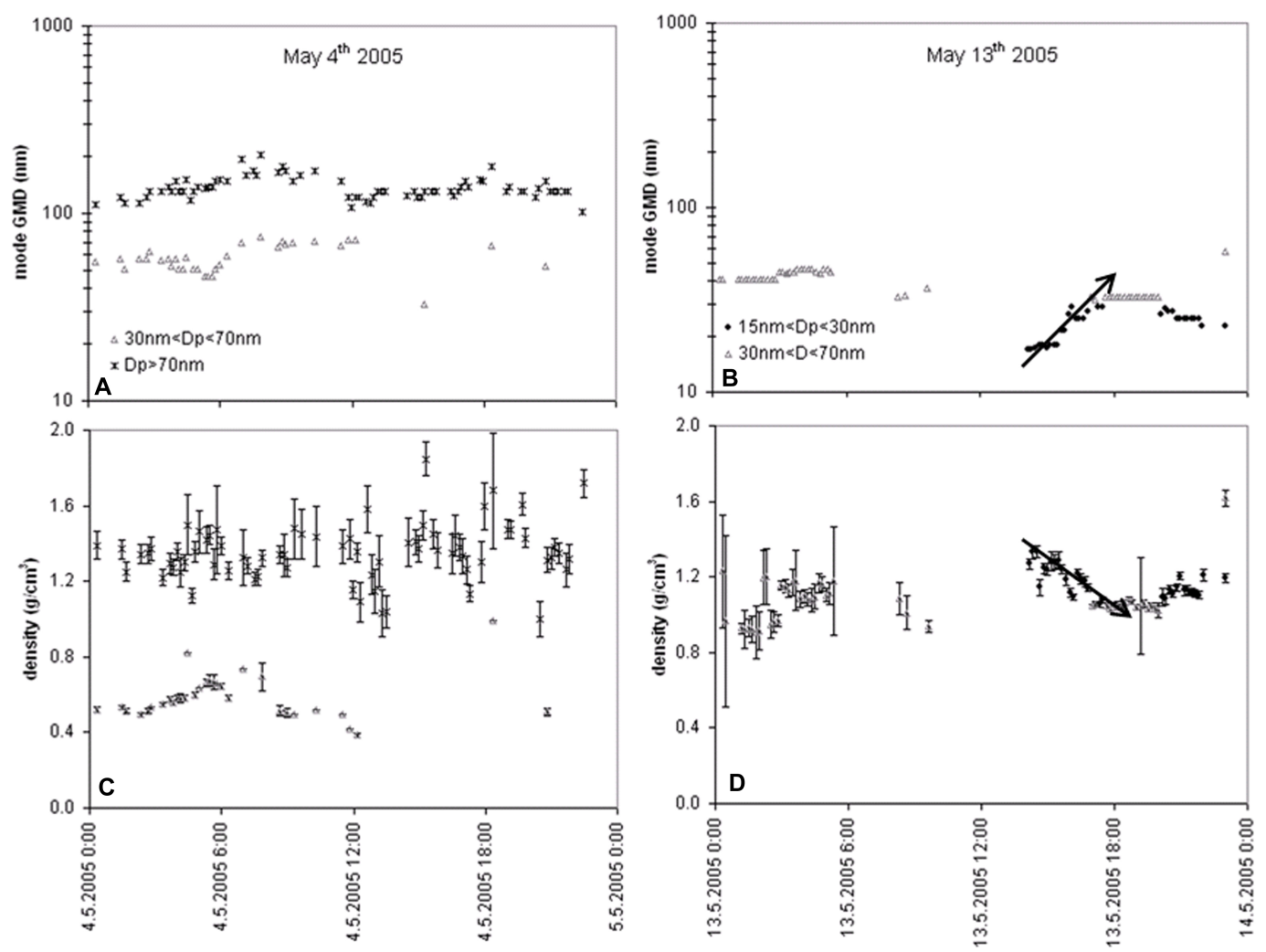

Fig. 7. The mode GMDs measured on 4th May (a) and 13th May (b) and the mode densities measured at 4th May (c) and 13th May (d). The arrows show the trend of decreasing nucleation mode particle density during the growth process.

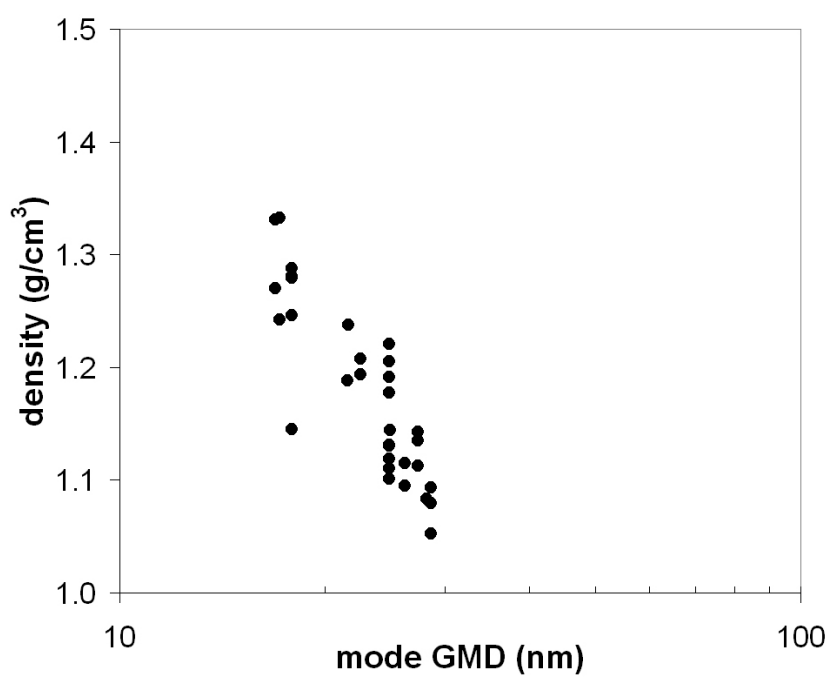

Fig. 8. The density of nucleation mode particles as a function of mode GMD during the growth process on 13th May.

very high and the accumulation mode concentration was very low. The density of the nucleation mode peaking, at $17 \mathrm{~nm}$, was approximately $1.3 \mathrm{~g} / \mathrm{cm}^{3}$ (Fig. $6 \mathrm{~b}$ and d). The newly formed nucleation mode particles grew until they achieved a stable mode diameter of approximately $33 \mathrm{~nm}$ at around 06:00 p.m. The density of grown $33 \mathrm{~nm}$ particles levelled at $1.0 \mathrm{~g} / \mathrm{cm}^{3}$ (Fig. $7 \mathrm{~d}$ ). The particle density decreased simultaneously with the particle growth process indicating the condensation of some lighter compounds. Starting at 19:20, the mode diameter decreased from $33 \mathrm{~nm}$ to $20 \mathrm{~nm}$ (Fig. $7 \mathrm{~b}$ ). At the same time, the particle density increased from $1 \mathrm{~g} / \mathrm{cm}^{3}$ to $1.2 \mathrm{~g} / \mathrm{cm}^{3}$ (Fig. 7d).

The density decrease associated with the particle growth process during the particle formation event on 13th May is indicated in Fig. $7 \mathrm{~b}$ and $7 \mathrm{~d}$ by the arrows. The density values of the nucleation mode particles during the growth process on 13th May are presented as a function of mode GMD in Fig. 8. Assuming spherical particles, the density of the condensing species can be estimated calculating the change in particle mass during the growth process. In calculations we have assumed that the change in mode GMD corresponds to the increase in the particle size and thus the GMD values and the related density values have been used (see Fig. 8). The resulted density estimate for the condensing species was $1.0 \pm 0.2 \mathrm{~g} / \mathrm{cm}^{3}$. Similar density decrease of the growing nucleation mode particles was seen also on $3 \mathrm{rd}, 11 \mathrm{th}$, and 12 th May. The above analysis for the growth process of nucleation mode particles was performed also for the data acquired on those days. The density data of 14th and 15th May were 
too unstable for such analysis. On 3rd May the density of the species condensing on the nucleation mode particles was $0.5 \pm 0.2 \mathrm{~g} / \mathrm{cm}^{3}$. This is in a good agreement with the low density values of the Aitken mode particles detected in the first days of the campaign. On 11th May and 12th, the corresponding density was $0.7 \pm 0.3 \mathrm{~g} / \mathrm{cm}^{3}$.

\section{Conclusions}

We have presented the simultaneously measured density values of atmospheric nucleation, Aitken and accumulation mode particles. The Aitken and the accumulation mode particle densities had the lowest values in the beginning of the campaign. This period coincide with the days during which no nucleation mode formation occurred. On the other hand, the highest values of the Aitken mode densities (0.9$1.3 \mathrm{~g} / \mathrm{cm}^{3}$ ) were recorded within the period during which the particle formation events occurred. This indicates that the composition of the Aitken mode particles is different within these two periods. The results indicate that the method employed in this study allows us to investigate the time dependent density behaviour of different modes. These kinds of results are new and give an interesting insight to the atmospheric processes.

Also the density progress of the nucleation mode particles was investigated. When a particle formation event was recorded, a significant change in the nucleation mode particle densities was detected: the density of the nucleation mode particles decreased during the growth process. According to authors' knowledge, there are no prior data on the development of the particle density of the nucleation mode during the growth process. Our results indicate that the initial particles formed by nucleation consisted of denser species (the density of $17 \mathrm{~nm}$ particles was around $1.3 \mathrm{~g} / \mathrm{cm}^{3}$ ). The growth of the particles occurred by the condensation of lighter compounds.

Our results support the common assumption according to which the particle growth may occur by the condensation of the species that do not contribute to the initial nucleation process. The low density values also indicate that the condensing species might be organic compounds. A number of different organic species have been related to the particle growth process in natural forest environment (e.g. Mäkelä et al., 2001a; O’Dowd, 2002; Tarvainen et al., 2005; Laaksonen et al., 2008) and the density of those species vary between $0.5 \mathrm{~g} / \mathrm{cm}^{3}$ and $1.9 \mathrm{~g} / \mathrm{cm}^{3}$. Longer data collection, a more detailed analysis and additional measurements of e.g. VOC emissions are needed before the found density can be related to any specific species. This is a subject for further studies. We also found out that the density of the condensing species was lower at the beginning of the campaign (3rd May) than it was at the end of the campaign (10th-18th May). The reason for this phenomenon is still unclear and a longer data set is needed to find the reason. It should be noted, that the results derived here for the forest aerosol, will apply only for rather clean ambient conditions. It is assumed that in e.g. urban air masses, different compounds are present and therefore different particle densities for the modes will prevail.

Acknowledgements. The study has been funded by Maj and Tor Nessling foundation. The authors wish to thank Jyrki Ristimäki, presently at Wärtsilä Finland $\mathrm{Oy}$, for his kind co-operation and $\mathrm{Mr}$ Matti Happonen for language edition.

Edited by: A. Wiedensohler

\section{References}

Aalto P., Hämeri, K., Becker, E., Weber, R., Salm, J., Mäkelä, J. M., Hoell, C., O’Dowd, C. D., Karlsson, H., Hansson, H.-C., Väkevä M., Koponen, I. K., Buzorius, G., and Kulmala, M.: Physical characterization of aerosol particles during nucleation events, Tellus, 53B, 344-358, 2001.

Alam, A., Shi, J. P., and Harrison, R. M.: Observations of new particle formation in urban air, J. Geophys. Res., 108, D3, 4093, doi:10.1029/2001JD001417, 2003.

Allan, J. D., Alfarra, M. R., Brower, K. N., Coe, H., Jayne, J. T., Worsnop, D. R., Aalto, P. P., Kulmala, M., Hyötyläinen, T., Cavalli, F., and Laaksonen, A.: Size and composition measurements of background aerosol and new particle growth in a Finnish forest during QUEST 2 using an Aerodyne Aerosol Mass Spectrometer, Atmos. Chem. Phys., 6, 315-327, 2006, http://www.atmos-chem-phys.net/6/315/2006/.

Allen, J. O., Durant, J. L., Dookeran, N. M., Taghizadeh, K., Plummer, E. F., Lafleur, A. L., Sarofim, A. F., and Smith, K. A.: Measurement of $\mathrm{C}_{24} \mathrm{H}_{14}$ Polycyclic Aromatic Hydrocarbons Associated with a Size-Segregated Urban Aerosol, Environ. Sci. Technol., 32, 13, 1928-1932, 1998.

Cass, G. R., Hughes, L. A., Bhave, P., Kleeman, M. J., Allen, J. O., and Salmon, L. G.: The Chemical Composition of Ultrafine Particles, Philos. T. Roy. Soc. A., 358, 2581-2592, 2000.

Charron, A., Birmili, W., and Harrison, R. M.: Factors influencing new particle formation at the rural site, Harwell, UK, J. Geophys. Res., 112, D14210, doi:10.1029/2007JD008425, 2007.

Cozic, J., Verheggen, B., Weingartner, E., Crosier, J., Bower, K., Flynn, M., Coe, H., Henning, S., Steinbacher, M., Collaud Coen, M., Petzold, A., and Baltensperger, U.: Chemical composition of free tropospheric aerosol for PM1 and coarse mode at the high alpine site Jungfraujoch, Atmos. Chem. Phys., 8, 407-423, 2008, http://www.atmos-chem-phys.net/8/407/2008/.

Dal Maso, M., Kulmala, M., Riipinen, I., Wagner, R., Hussein, T., Aalto, P.P., and Lehtinen, K. E. J.: Formation and growth of fresh atmospheric aerosols: eight years of aerosol size distribution data from SMEAR II, Hyytiala, Finland, Boreal Environ. Res., 10, 323-336, 2005.

Hari, P. and Kulmala, M.: Station for Measuring EcosystemsAtmosphere Relations (SMEAR II), Boreal Environ. Res. 10, 315-322, 2005.

Harrison, R. M., Grenfell, J. L., Savagen, N., Allen, A., Clemitshaw, K. C., Penkett, S., Hewitt, C. N., and Davison, B.: Observations of new particle production in the atmosphere of a moderate polluted site in eastern England, J. Geophys. Res., 105, D14, 17 819-17 832, 2000. 
Hussein, T., Puustinen, A., Aalto, P. P., Mäkelä, J. M., Hämeri, K., and Kulmala, M.: Urban aerosol number size distributions, Atmos. Chem. Phys., 4, 391-411, 2004, http://www.atmos-chem-phys.net/4/391/2004/.

Hussein, T., Dal Maso, M., Petaja, T., Koponen, I. K., Paatero, P., Aalto, P. P., Hämeri, K., and Kulmala, M.: Evaluation of an automatic algorithm for fitting the particle number size distributions, Boreal Environ. Res., 10, 337-355, 2005.

Kannosto, J., Ristimäki, J., Virtanen, A., Keskinen, J., Aalto, P., and Kulmala, M.: Density analysis of boreal forest aerosols, Chemical Engineering Transactions, 10, 95-99, 2006.

Keskinen, J., Marjamäki, M., Virtanen, A., Mäkelä, T., and Hillamo, R.: Electrical Calibration Method for Cascade Impactors, J. Aerosol Sci., 30, 111-116, 1999.

Koponen, I., Virkkula, A., Hillamo, R., Kerminen, V.-M., and Kulmala, M.: Number size distributions and concentrations of the continental summer aerosols in Queen Maud Land, Antartica, J. Geophys. Res., 108, D18, 45872002, doi:10.1029/2003JD003614, 2003.

Kulmala, M., Hämeri, K., Aalto, P. P., Mäkelä, J. M., Pirjola, L., Nilsson, E. D., Buzorius, G., Rannik, U., Dal Maso, M., Seidl, W., Hoffman, T., Janson, R., Hansson, H. C., Viisanen, Y., Laaksonen, A., and O'Dowd, C. D.: Overview of the international project on biogenic aerosol formation in the boreal forest (BIOFOR), Tellus, 53B, 324-343, 2001.

Kulmala, M., Vehkamäki, H., Petäjä, T., Dal Maso, M., Lauri, A., Kerminen, V.-M., Birmili, W., and McMurry, P. H.: Formation and growth rates of ultrafine atmospheric particles: A review of observations, J. Aerosol Sci. 35, 143-176, 2004a.

Kulmala, M., Laakso, L., Lehtinen, K. E. J., Riipinen, I., Dal Maso, M., Anttila, T., Kerminen, V.-M., Hõrrak, U., Vana, M., and Tammet, H.: Initial steps of aerosol growth, Atmos. Chem. Phys., 4, 2553-2560, 2004b, http://www.atmos-chem-phys.net/4/2553/2004/.

Kulmala, M., Lehtinen, K. E. J., and Laaksonen, A.: Cluster activation theory as an explanation of the linear dependence between formation rate of $3 \mathrm{~nm}$ particles and sulphuric acid concentration, Atmos. Chem. Phys., 6, 787-793, 2006,

http://www.atmos-chem-phys.net/6/787/2006/.

Laaksonen, A., Kulmala, M., O’Dowd, C. D., Joutsensaari, J., Vaattovaara, P., Mikkonen, S., Lehtinen, K. E. J., Sogacheva, L., Dal Maso, M., Aalto, P., Petäjä, T., Sogachev, A., JunYoon, Y., Lihavainen, H., Nilsson, D., Facchini, M. C., Cavalli, F., Fuzzi, S., Hoffmann, T., Arnold, F., Hanke, M., Sellegri, K., Umann, B., Junkermann, W., Coe, H., Allan, J. D., Rami Alfarra, M., Worsnop, D. R, Riekkola, M.-L., Hyötyläinen T., and Viisanen, Y.: The role of VOC oxidation products in continental new particle formation, Atmos. Chem. Phys., 8, 2657-2665, 2008, http://www.atmos-chem-phys.net/8/2657/2008/.

Lohman, U. and Feichter, J.: Global indirect aerosol effects: a review, Atmos. Chem. Phys., 5, 715-737, 2005, http://www.atmos-chem-phys.net/5/715/2005/.

Maenhaut, W., Jaffrezo, J.-L., Hillamo, R. E., Mäkelä, T., and Kerminen, V.-M.: Size-fractionated aerosol composition during an intensive 1997 summer field campaign in northern Finland, Nucl. Instrum. Methods, B150, 345-349, 1999.

Marjamaki, M., Keskinen, J., Chen., D. R., and Pui, D. Y. H.: Performance evaluation of the electrical low-pressure impactor (ELPI), J. Aerosol Sci., 31, 249-261, 2000.
Marjamäki, M., Lemmetty, M., and Keskinen, J.: ELPI response and data reduction - I: Response functions, Aerosol Sci. Tech., 39, 575-582, 2005.

McMurry, P., Wang, X., Park, K., and Ehara, K.: The relationship between mass and mobility for atmospheric particles: A new technique for measuring particle density, Aerosol Sci. Tech., 36, 227-238, 2002.

Mäkelä, M., Aalto, P., Jokinen, V., Pohja, T., Nissinen, A., Palmroth, S., Markkanen, T., Seitsonen, K., Lihavainen, H., and Kulmala, M.: Observations of ultrafine aerosol particle formation and growth in boreal forest, Geophys. Res. Lett., 24, 1219-1222, 1997.

Mäkelä, J. M., Hoffmann, T., Holzke, C., Väkevä, M., Suni, T., Mattila, T., Aalto, P. P., Tapper, U., Kauppinen, E. I., and O’Dowd, C. D.: Biogenic iodine emissions and identification of end products in coastal ultrafine particles during nucleation bursts, J. Geophys. Res., 107, 8110, doi:10.1029/2001JD000580, 2002.

Mäkelä, J., Koponen, I., Aalto, P., and Kulmala, M.: One-year data of submicron size modes of tropospheric background aerosol in southern Finland, J. Aerosol Sci., 31, 595-611, 2001b.

Mäkelä, J. M., Yli-Koivisto, S., Hiltunen, V., Seidl, W., Swietlicki, E., Teinilä, K., Sillanpää, M., Koponen, I. K., Paatero, J., Rosman, K., and Hämeri, K.: Chemical composition of aerosol during particle formation events in boreal forest, Tellus, 53B, 380393, 2001a.

O’Dowd, C. D., Aalto, P., Hämeri, K., Kulmala, M., and Hoffmann, T.: Atmospheric particles from organic Vapours, Nature, 416, 497-498, 2002.

Pope, C. A. and Dockery, D. W.: Health Effects of Fine Particulate Air Pollution: Lines that Connect, J. Air Waste Manage. Assoc., 56, 709-742, 2006.

Putaud, J.-P., Van Dingenen, R., Dell'Acqua, A., Raes, F., Matta, E., Decesari, S., Facchini, M. C., and Fuzzi, S.: Size-segregated aerosol mass closure and chemical composition in Monte $\mathrm{Ci}$ mone (I) during MINATROC, Atmos. Chem. Phys., 4, 889-902, 2004, http://www.atmos-chem-phys.net/4/889/2004/.

Ristimäki, J., Virtanen, A., Marjamäki, M., Rostedt, A., and Keskinen, J.: On-line measurement of size distribution and effective density of submicron aerosol particles, J. Aerosol Sci., 33, 15411557, 2002.

Ristimäki, J.: Sampling and measurement methods for diesel exhaust aerosol, Tampere University of Technology Publications, 638, PhD Thesis, 2006.

Saarikoski, S., Mäkelä, T., Hillamo, R., Aalto, P., Kerminen, V.-M., and, Kulmala, M.: Physico-chemical characterization and mass closure of size-segregated atmospheric aerosols in Hyytiälä, Finland, Boreal Environ. Res., 10, 385-400, 2005.

Seinfeld, J. H. and Pandis, S. N.: Atmospheric chemistry and physics. From air pollution to climate change, John Wiley \& Sons, 429-443, New York, 1998.

Smith, J. N., Moore, K. F., Eisele, F. L., Voisin, D., Ghimire, A. K., Sakurai, H., and McMurry, P. H.: Chemical composition of atmospheric nanoparticles during nucleation events in Atlanta, J. Geophys. Res., 110, D22S03, doi:10.1029/2005JD005912, 2005.

Tarvainen, V., Hakola, H., Hellen, H., Back, J., Hari, P., and Kulmala, M.: Temperature and light dependence of the VOC emissions of Scots pine, Atmos. Chem. Phys., 5, 989-998, 2005, http://www.atmos-chem-phys.net/5/989/2005/. 
Vaattovaara, P., Huttunen, P. E., Yoon, Y. J., Joutsensaari, J., Lehtinen, K. E. J., O'Dowd, C. D., and Laaksonen, A.: The composition of nucleation and Aitken modes particles during coastal nucleation events: evidence for marine secondary organic contribution, Atmos. Chem. Phys., 6, 4601-4616, 2006,

http://www.atmos-chem-phys.net/6/4601/2006/.

Virtanen, A., Ristimäki, J., and Keskinen, J.: New method to define the effective density and fractal dimension of agglomerate particles, Aerosol Sci. Tech., 38, 437-446, 2004.

Virtanen, A., Rönkkö, T., Kannosto, J., Ristimäki, J., Mäkelä, J. M., Keskinen, J., Pakkanen, T., Hillamo, R., Pirjola, L., and Hämeri, K.: Winter and summer time size distributions and densities of traffic related aerosol particles at a busy highway in Helsinki, Atmos. Chem. Phys., 6, 2411-2421, 2006,

http://www.atmos-chem-phys.net/6/2411/2006/.

Wall, S. M., John, W., and Ondo, J. L.: Measurement of aerosol size distributions for nitrate and major ionic species, Atmos. Environ., 22, 1649-1656, 1988.

Wehner, B. and Wiedensohler, A.: Long term measurement of submicrometer urban aerosols: statistical analysis for correlations with meteorological conditions and trace gases, Atmos. Chem. Phys., 3, 867-879, 2003, http://www.atmos-chem-phys.net/3/867/2003/.

Wehner, B., Wiedensoler, A., Tuch, T. M, Wu, Z. J., Hu, M., Slanian, J., and Kiang, S. C.: Varability of the aerosol number size distribution in Beijing, China: New particle formation, dust storms, and high concentration backgrounds, Geophys. Res. Lett., 31, L22108, doi:10.1029/2004GL023827, 2005.
Yu, H., Kaufman, Y. J., Chin, M., Feingold, G., Remer, L. A., Anderson, T. L., Balkanski, Y., Bellouin, N., Boucher, O., Christopher, S., DeCola, P., Kahn, R., Koch, D., Loeb, N., Reddy, M. S., Schulz, M., Takemura, T., and, Zhou M.: A review of measurement-based assessment of the aerosol direct radia-tive effect and forcing, Atmos. Chem. Phys., 6, 613-666, 2006, http://www.atmos-chem-phys.net/6/613/2006/.

Zhang, O., Canagaratna, M. R., Jayne, J. T., Worsnop, D. R., and Jimenez, J.-L.: Time- and size-resolved chemical composition of submicron particles in Pittsburgh: Implications for aerosol sources and processes, J. Geophys. Res, 110, D07S09, doi:10.1029/2004JD004649, 2005.

Zhang, Q., Stainer, C. O., Canagaratna, M. R., Jayne, J. T., Worsnop, D. R., Pandis, S. N., and Jimenez, J. L.: Insight into chemistry of new particle formation and growth events in Pittspurgh based on aerosol mass spectrometry, Environ. Sci. Tech., 38, 4797-4809, 2004a.

Zhang, R., Suh, I., Zhao, J., Zhang, D., Fortner, E., Tie, X., Molina, L. T., and Molina, M. J.: Atmospheric new particle formation enhanced by organic acids, Science, 304, 1487-1490, 2004b. 